\title{
STABILITY OF WIDE FORMAT INK JET PRINTS FOR OUTDOOR APPLICATION
}

\author{
Igor Sinđić, Ivana Bolanča Mirković, Zdenka Bolanča
}

Original scientific paper In this paper the research results of the weather resistance of the Ink Jet wide format prints obtained by piezoelectric technology with pigment-based and UV curable inks are presented. The samples were exposed to the real outdoor conditions. Changes in the optical characteristics of the substrate as colour difference and gamut volume of prints in relations to the global and diffusion radiation, air temperature and humidity are presented. The results show that $\Delta E^{*}$ for yellow and slightly less for the black on prints with UV curable inks exposed in summer is less in the period when gamut volume increases with time of exposure due to global radiation increase. Gamut volume of prints with UV curable inks increases during winter, as well as in the specific time interval in summer to subsequently reducing with further exposing. However, the gamut volume of prints with pigment-based ink is reduced during exposing, and $\Delta V$ for daylight exposing is $37 \%$ higher compared to winter.

Keywords: atmospheric properties; CIE $L^{*} a^{*} b^{*}$; gamut; ink jet; outdoor exposing; prints stability

\section{Stabilnost inkjet otisaka velikog formata za vanjsku primjenu}

U ovom radu se prikazuju rezultati istraživanja otpornosti na vremenske uvjete inkjet otisaka velikog formata dobivenih piezo-električnom tehnologijom s bojilima na osnovi pigmenata i UV sušećim bojilima. Uzorci su izlagani stvarnim vanjskim uvjetima. Prikazuju se promjene optičkih karakteristika podloge kao i razlika obojenja te volumen gamuta otisaka u odnosu na globalno i difuzno zračenje, temperaturu i vlagu zraka. Rezultati pokazuju da $\Delta E^{*}$ za žuto i crno bojilo na otisku s UV sušećim bojilom eksponiranom ljeti, je manje u periodu kada se utvrđuje povećanje volumena gamuta tijekom izlaganja, između ostalog i radi većeg globalnog zračenja. Volumen gamuta otiska s UV sušećim bojilima se povećava tijekom zimskog izlaganja, kao i do određenog vremenskog intervala u ljetnom izlaganju, da bi se nakon toga s daljnjim izlaganjem smanjivao. Međutim, volumen gamuta otisaka s bojilima na osnovi pigmenta smanjuje se tijekom izlaganja, a $\Delta V$ za ljetno izlaganje je $37 \%$ veće u odnosu na zimsko.

Ključne riječi: CIE L*a* H*; $^{*}$ gamut; inkjet; stabilnost otiska; svojstva atmosfere; vanjsko izlaganje

\section{Introduction}

Stability of ink jet prints is affected by simultaneous action of radiation and atmospheric properties. Sunlight, heat, moisture and air pollution can cause serious prints deterioration: colour change, fading, cracking, peeling, oxidation and loss of strength [1].

The effect of weathering cannot be examined in terms of the ink alone and must take into account the substrate upon which the ink is printed.

Many researchers were to develop ink jet media, including those for outdoor applications $[2 \div 5]$. Wu and co-authors were evaluating the effect of coating porosity on inkjet colour and light-fastness performance [6]. They were fumed silica blended with precipitated calcium carbonate. It was found that addition of PCC in the coating formulated to increase the UV resistance of the coating with a slightly higher $\mathrm{pH}$ value of coating.

The light-fastness of prints is understood as its resistance to the action of daylight without the direct influence of weather [7].

Chovancova-Lowell and Fleming were investigating the optical and physical properties and colour performance of different substrates with special Ink Jet receptive coating layer with and without optical brightening agents [8]. The smallest colour difference was found for optical brightening agents-free substrates. In terms of the least loss of colour data, the optical brightening agents-free substrates show the best lightfastness performance.

The role of the structural properties of the coating (PCC: kaolin ratio), with dye based inks decreased with an increase in the strength of the chemical paper/ink interaction [9]. The light-fastness of the prints was improved when the porosity of the coating decreased as a result of increased binder content.

Halinova et al. investigated light-fastness of inks printed by Ink Jet (Epson Stylus 808, HP DeskJet 920c) and laser printers (Minolta Color Page Pro plus, Minolta DiAlTAColor CF 1501) on different types of papers artificially aged by different types of light sources (sunlight, radiation middle pressure $\mathrm{Hg}$ discharge lamp with luminophor and florescent tube) [10]. The highest colour difference was observed for magenta ink printed by ink jet printers and cyan inks printed by laser printers.

The influence of the spectral composition of light on paper and ink jet print stability was studied by Blaznik et al. [11].

Different Ink Jet Epson printers and their ink sets were studied in terms of printability tests, particle size analyses, colour gamut and fading tests [12]. It can be concluded that the inks with pigment particles encapsulated in specific resins is able to approach the properties of the dye based inks, especially in the term of gamut width. Matte paper in combination with pigment based inks gives the smallest colour gamut compared to the gamut of glossy paper.

Colour gamut volume is increasingly being used as a tool for print durability estimation $[13 \div 17]$. Dobric and co-authors investigated change of the colour gamut volume immediately after the printing including drying phase, the ageing of prints in the closed space without the influence of radiation, exposing the prints in the air conditioned room to the mixed daylight and artificial light and exposing of prints to the sunlight through the glass window [13]. The aim of work from Bolanca Mirkovic and co-authors was to determine deviation of the colour and change of 3D gamut of the artificially and natural 
aged prints obtained on printers of different technologies (piezoelectric, thermal and UV) and their ecological characteristics [15].

Change of gamut volume during long period, sample exposed to the real conditions and evolution of the lightfastness of Ink Jet prints and photographs was investigated by Kacerova and co-authors [18]. The reflective spectra was measured, $L^{*} a^{*} b^{*}$ values were used for gamut visualization as $3 \mathrm{D}$ and gamut volume was evaluated by program VolGa. In the experimental conditions VIS radiation has the great impact on the dye degradation, especially on the degradation of yellow and magenta dye.

In this paper the results of the weather resistance of the Ink Jet wide format prints obtained by piezoelectric technologies with pigment-based and UV curable inks are presented. The samples were exposed to the real conditions in intervals of 7 days throughout the whole winter and summer period in densely populated Zagreb city area with heavy traffic. Changes in the optical characteristics of the substrate in this period as colour difference and gamut volume of prints are presented. Results are discussed in relation to the global and diffusion radiation, air temperature and humidity.

\section{Materials and methods}

The prints obtained by piezoelectric ink jet technology with pigment-based and UV curable inks were used in the research. The following printers were used: HP DesignJet 9000s and Roland Versa UV LEC 300. These printers are used for wide formats of the prints for outdoor applications.

HP DesignJet 9000s uses piezoelectric ink jet technology. The printing resolution is $720 \times 720$ dpi. Six printing heads were used for printing (CMYK $+\mathrm{C}_{\mathrm{L}}+$ $M_{L}$ ). Low-solvent inks were used for printing [19].This printer uses carbon filters to absorb the air volatile organic compounds released during the printing process. The system is designed to absorb VOC from air at rates consistent with the print speed and number of compounds released during printing.

Roland Versa UV LEC 300 uses ECO UV curable inks and dual UV LED lamp. With Versa UV power consumption during peak printing periods is just $320 \mathrm{~W}$ much lower than that of typical UV printer equipped with mercury lamps. The traditional production technology of high pressure mercury lamp is primarily because of high costs of equipment, high temperatures of irradiated components, hazard to human health or the environment when improperly managed. Versa UV LED lamp can be used at least up to 10000 hours. In addition the unit's temperature remains relatively cool during printing for safer operation. For printing with Roland Versa UV LEC were used CMYK + White ink jet inks [20]. Low viscous acrylic acid ester in UV inks in touch with human skin can cause allergic symptoms. Therefore it is necessary to increase the safety level of the UV cure inks.

The test chart contains the following printing elements: CMYK step-like wedges ranging from $10 \div 100$ $\%$ screen value and standard wedge with 378 patches for making the ICC profile and $3 \mathrm{D}$ gamut. Matt coated paper was used for printing. Optical and colorimetric properties of paper are shown in Tab. 1. The analyses were measured on the basis of ISO and TAPPI standard methods: ISO brightness (ISO 2470), opacity (ISO 2471), light scattering and light absorption (ISO 9416), CIE whiteness (ISO 11475), and colour properties of paper

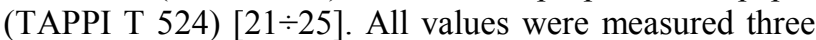
times and average values were used for further analysis.

Table 1 Optical and colorimetric properties of paper

\begin{tabular}{|l|c|}
\hline \multicolumn{1}{|c|}{ Properties } & Values \\
\hline ISO brightness $\%$ & 91,17 \\
\hline CIE whiteness UV inc. & 128,37 \\
\hline CIE whiteness UV excl. & 84,14 \\
\hline$L^{*}$ & 94,06 \\
\hline$a^{*}$ & 4,26 \\
\hline$b^{*}$ & $-9,74$ \\
\hline ISO opacity $\%$ & 98,28 \\
\hline Scattering coefficient $\mathrm{m}^{2} / \mathrm{kg}$ & 63,3 \\
\hline Absorption coefficient $\mathrm{m}^{2} / \mathrm{kg}$ & 0,8 \\
\hline
\end{tabular}

The paper and print samples were subject to controlled outdoor exposure test (ASTM D 3424) [26]. These are arranged as a series of papers and prints and set into a frame arrayed at 45 degrees from the vertical south facing in the northern hemisphere, to receive maximum sunlight.

The samples were exposed to the real conditions in intervals of 7 days throughout the whole winter and summer period in densely populated area of the city with heavy traffic. At the same location in the same time interval meteorological data were measured: the global and diffuse radiation, air temperature and humidity [27].

Exposed paper samples were measured as described above optical and colorimetric properties.

The unexposed and outdoor exposed samples were evaluated by spectrophotometer measurements. The spectrophotometer X Rite DTP 41 and the application ColourShop $\mathrm{X}$ were used for calculating output results such as: $L^{*} a^{*} b^{*}, c^{*}, H^{*}, x, y, Y$, and spectral reflection in the visible part of the spectrum. All values were measured three times and average values were used for further analysis. The colour difference $\Delta E_{2000}^{*}$ was calculated using the following equations [28, 29].

$\Delta E_{2000}^{*}=\sqrt{\left(\frac{\Delta L^{*}}{S_{L} k_{L}}\right)^{2}+\left(\frac{\Delta C^{*}}{S_{C} k_{C}}\right)^{2}+\left(\frac{\Delta H^{*}}{S_{H} k_{H}}\right)^{2}+R_{T}\left(\frac{\Delta C^{*}}{S_{C} k_{C}}\right) \cdot\left(\frac{\Delta H^{*}}{S_{H} k_{H}}\right)} \cdot(1)$

In equations $\Delta E^{*}$ is the colour difference, $\Delta L *$ is the light difference, $\Delta C^{*}$ is the chroma difference, $\Delta H^{*}$ is the hue difference and $k_{L}, k_{C}, k_{H}$ are parametric weighting factors.

Other parameters are defined as follows:

$$
\begin{aligned}
& S_{L}=1+\frac{0,015 \cdot\left(\overline{L^{\prime}}-50\right)^{2}}{\sqrt{20+\left(\overline{L^{\prime}}-50\right)^{2}}}, \\
& S_{C}=1+0,045 \cdot C^{\prime}, \\
& S_{H}=1+0,015 \cdot \bar{C} T, \\
& T=1-0,17 \cdot \cos \left(h^{\prime}-20^{\circ}\right)+0,24 \cdot \cos \left(2 h^{\prime}\right)+ \\
& +0,32 \cdot \cos \left(3 h^{\prime}+6^{\circ}\right)-0,20 \cdot \cos \left(4 h^{\prime}-63^{\circ}\right),
\end{aligned}
$$




$$
\begin{aligned}
& R_{C}=2 \sqrt{\frac{\bar{C}^{\prime 7}}{\bar{C}^{\prime 7}+25^{7}},} \\
& R_{T}=-\sin (2 \Delta \theta) R_{C}, \\
& \Delta \theta=30 \cdot \exp \left\{-\left[\frac{h^{\prime}-275^{\circ}}{25}\right]^{2}\right\} .
\end{aligned}
$$

The presented pattern includes the following modifications: a hue rotation term to deal with the problematic blue region, compensation for neutral colours (the primed values in the $L^{*}, C^{*}, h$ differences), a compensation for lightness, a compensation for chroma and a compensation for hue. The X-Rite DTP 41 device is suitable for measuring a large number of patches (in this case the test cart with 378 colour patches).

The measurements were used to create the ICC profiles using the program MonacoProfiler Platinum $\mathrm{v}$ 4.8. From the generated ICC profiles space the colour gamut was formed and gamut volumes were detected in the program Gamut Works v.1.0. Three characteristic cross-sections of gamut for lightness L20, L50 and L80 were done.

\section{Results and discussion}

The impact of weathering on optical properties of substrate such as brightness, opacity, scattering and absorption of light for coated paper which was exposed in three winter months and three summer months were presented in Tab. 2.

Table 2 Optical properties of paper in function of weathering

\begin{tabular}{|c|c|c|c|c|}
\hline Samples & $\begin{array}{c}\text { ISO } \\
\text { brightness } \\
\%\end{array}$ & $\begin{array}{c}\text { Opacity } \\
\%\end{array}$ & $\begin{array}{c}\text { Scattering } \\
\text { coefficient } \\
\mathrm{m}^{2} / \mathrm{kg}\end{array}$ & $\begin{array}{c}\text { Absorption } \\
\text { coefficient } \\
\mathrm{m}^{2} / \mathrm{kg}\end{array}$ \\
\hline $\begin{array}{c}\text { Before } \\
\text { exposing }\end{array}$ & 98,91 & 98,28 & 88,60 & 0,95 \\
\hline $\begin{array}{c}\text { After } \\
\text { winter } \\
\text { exposing }\end{array}$ & 90,97 & 98,53 & 84,70 & 1,35 \\
\hline $\begin{array}{c}\Delta \text { winter } \\
\text { exposing }\end{array}$ & 7,94 & 0,25 & 3,90 & 0,40 \\
\hline $\begin{array}{c}\text { After } \\
\text { summer } \\
\text { exposing }\end{array}$ & 89,87 & 98,92 & 82,50 & 1,49 \\
\hline $\begin{array}{c}\Delta \text { summer } \\
\text { exposing }\end{array}$ & 9,04 & 0,64 & 5,10 & 0,54 \\
\hline
\end{tabular}

Outdoor exposing of the paper samples caused changes of ISO brightness decreased significantly. Brightness gain of the paper after exposing in the three winter months was $\Delta_{\text {brightness }}=7,94$ while after exposing in the three summer months was $\Delta_{\text {brightness }}=9,04$ (Tab. 2 ).

Measurements were made both with and without the UV component of illumination and this enabled the contribution of optical brightening agents to the brightness component to be calculated. In Table 3 the loss of brightness excluding UV due to yellowing of the paper and the loos of brightness including UV due to degradation of the optical brightening agents were presented. The results show that the brightness decreased and yellowness increased, due both to a yellowing of the paper and to the degradation of the optical brighteners. For outdoor exposing of paper in the summer months this process is even more evident.

Reducing the brightness can also be caused by oxidative degradation of low molecular parts of carbohydrate to form a carboxyl group, as evidenced by FTIR spectroscopy [30]. The increase of yellowness comes due to exposing paper to radiation of visible part of spectrum, but even without this influence when the paper is exposed to elevated temperatures and humidity.

Opacity is a measure of media ability to avoid penetration of light from one side to the other expressed as a ratio of the single sheet reading to the reference one. In accordance with the Kubelka-Munk theory opacity is determined by the values of the scattering coefficient and with absorption coefficient. An important influence on the opacity value can also be expected in terms of the type and amount of substances in the formulation of paper which except the fillers include for example chemical pulp, by which less opacity is attached. The results in Tab. 2 show that the opacity does not change considerably with exposing the paper to weathering in winter and summer.

The changes in opacity are caused both by increased light absorption coefficient and by decreased light scattering coefficient (Tab. 2). Apart from external impact on the absorption coefficient, effect of the endogenous factor which includes the substances from the domain of paper formulation, such as fillers is also possible. As is known, e.g. calcium carbonate can affect the reduction of the absorption coefficient. The lower values of light absorption increase paper opacity and consequently the visual appearance of an end product.

Table 3 Brightness data with and without UV before and after exposing to weathering

\begin{tabular}{|c|c|c|c|c|c|c|c|c|}
\hline \multirow{2}{*}{$\begin{array}{c}\text { Sample } \\
\text { exposing }\end{array}$} & \multicolumn{2}{|c|}{ Brightness without UV } & \multicolumn{2}{|c|}{ Brightness with UV } & \multicolumn{2}{|c|}{$\begin{array}{c}\text { Brightness due to optical } \\
\text { brighteners }\end{array}$} & \multicolumn{2}{|c|}{ Brightness loss due to exposing } \\
\cline { 2 - 10 } & $\begin{array}{c}\text { Before } \\
\text { exposing }\end{array}$ & $\begin{array}{c}\text { After } \\
\text { exposing }\end{array}$ & $\begin{array}{c}\text { Before } \\
\text { exposing }\end{array}$ & $\begin{array}{c}\text { After } \\
\text { exposing }\end{array}$ & Before & After & $\begin{array}{c}\text { Yellowing of } \\
\text { paper }\end{array}$ & $\begin{array}{c}\text { Loss of optical } \\
\text { brighteners }\end{array}$ \\
\hline winter & 85,3 & 78,6 & 90,1 & 81 & 4,8 & 1,5 & 6,7 & 1,9 \\
\hline summer & 87,3 & 78,3 & 92,8 & 82,1 & 5,5 & 3,8 & 9,0 & 3,5 \\
\hline
\end{tabular}

Ink jet paper since coatings are able to fix colorant rapidly and also to protect it from the environment. In this research is to measure the change in colour $\left(\Delta E^{*}\right)$ between two conditions their original, unexposed condition and their post-exposed, faded condition. Based upon the colour difference achieved and factoring in exposure time (meteorological data) conclusions may be concerning several factors: the colour strength and stability of pigment-based inks, as UV curing inks and any effect upon the optical brighteners in paper.

Fig. 1 shows colour difference of the Ink Jet prints with pigment-based and UV curing inks exposed to weathering in winter and summer. 

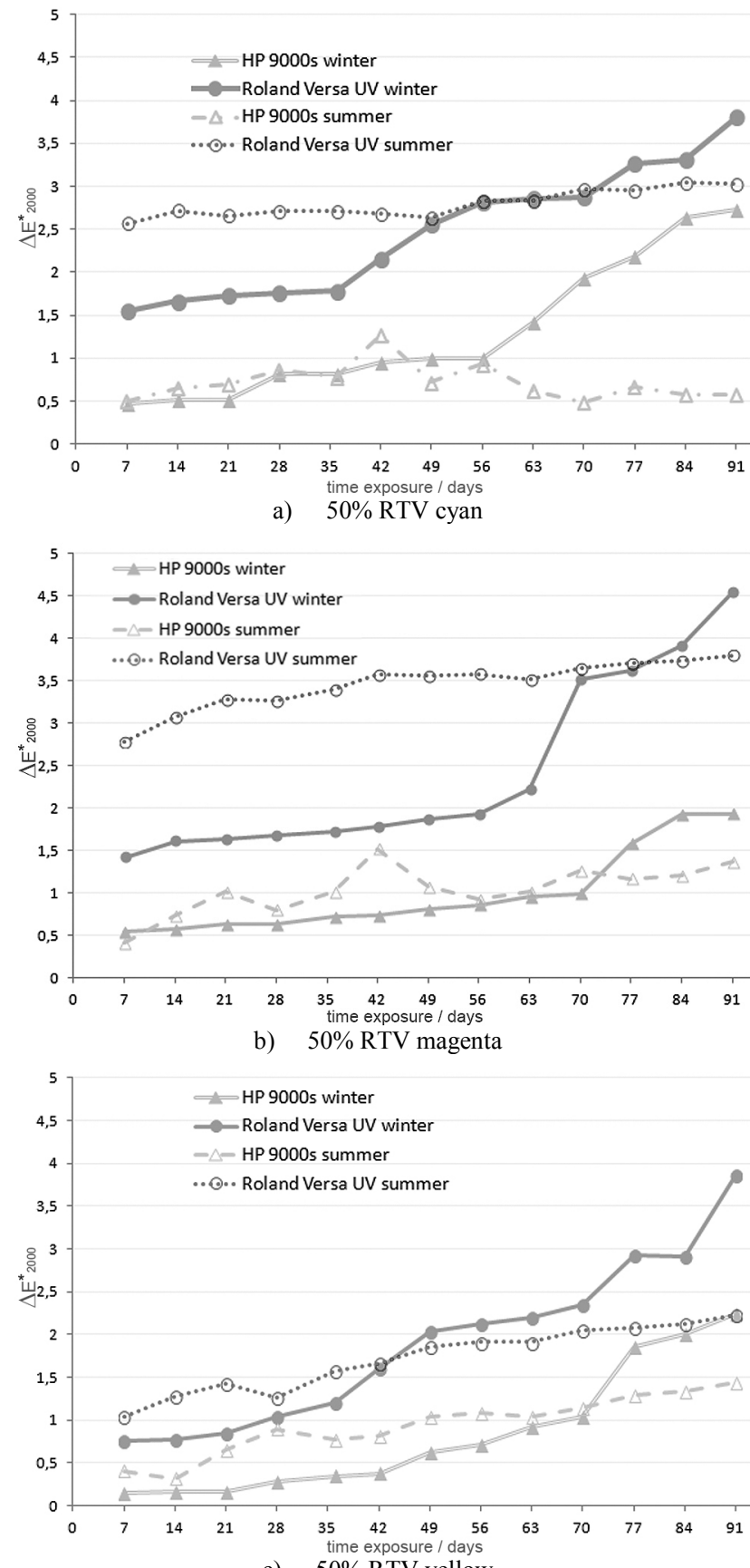

c) $50 \%$ RTV yellow

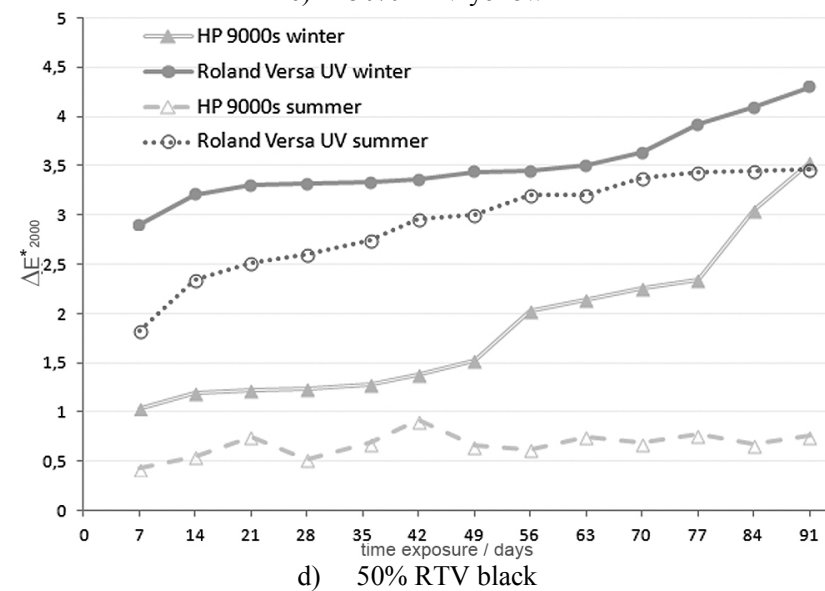

Figure 1 Colour difference for CMYK 50 RTV \% of the prints obtained by piezoelectric technology with pigment based inks and UV curable inks, on time exposure and weathering in winter and summer
The characteristic deviation in colour difference of 50 $\%$ CMYK halftone prints obtained by piezoelectric technology with pigment based inks exposed to environmental conditions in winter is higher compared to the ones exposed in summer $\left(\Delta E^{*}{ }_{50 \% \mathrm{C} \text { winter }}-\Delta E^{*}{ }_{50 \% \mathrm{C}}\right.$ summer $=0,57, \Delta E^{*}{ }_{50 \% \mathrm{M} \text { winter }}-\Delta E^{*}{ }_{50 \% \mathrm{M} \text { summer }}=0,56$, $\Delta E^{*}{ }_{50 \% \mathrm{Y} \text { winter }}-\Delta E^{*}{ }_{50 \% \mathrm{Y} \text { summer }}=0,81$ and $\Delta E^{*}{ }_{50 \% \mathrm{~K} \text { winter }}$ $\Delta E^{*}{ }_{50 \% \mathrm{~K} \text { summer }}=2,8$. This feature also applies to the full tone prints. Fluctuation of tones of halftone prints exposed to external conditions in winter ranges from the smallest obtained for magenta $\Delta E^{*}{ }_{50 \% \mathrm{M}}$ winter 1,93 to the biggest obtained for black $\Delta E^{*}{ }_{50 \% \mathrm{~K}}$ winter 3,56 , while in summer the smallest $\Delta E^{*}$ is obtained for cyan $\Delta E^{*}{ }_{50 \% \mathrm{C}}$ winter 3,81 , and the highest for magenta $\Delta \mathrm{E}^{*}{ }_{50 \% \mathrm{M} \text { winter }} 4,56$.

Colour difference of $50 \%$ halftone prints obtained by piezoelectric technology with UV curable inks has the same characteristic as the prints obtained by piezoelectric technology with pigment based inks, while prints exposed to outdoor conditions in winter have higher $\Delta E^{*}$ compared to those exposed in summer $\left(\Delta \mathrm{E}^{*}{ }_{50 \% \mathrm{C} \text { winter }}\right.$ $\Delta E^{*}{ }_{50 \% \mathrm{C} \text { summer }}=0,77, \Delta E^{*}{ }_{50 \% \mathrm{M} \text { winter }}-\Delta E^{*}{ }_{50 \% \mathrm{M} \text { summer }}=$ $0,76, \Delta E_{50 \% \mathrm{Y} \text { winter }}-\Delta E^{*}{ }_{50 \% \mathrm{Y} \text { summer }}=1,62$ and $\Delta E^{*}{ }_{50 \% \mathrm{~K}}$ winter $\left.-\Delta E_{50 \% \mathrm{~K} \text { summer }}=0,85\right)$. However, in this case such a characteristic does not apply to full tone prints where $\Delta E^{*}$ for cyan is higher in summer than in winter $\left(\Delta E^{*}{ }_{100 \% \mathrm{C}}\right.$ summer $=3,78, \Delta E^{*} 100 \% \mathrm{C}$ winter $\left.=1,99\right)$. The biggest colour difference change is determined in the winter while exposing $50 \%$ magenta halftone prints $\Delta E^{*}{ }_{50 \% \mathrm{M} \text { winter }}=$ 4,56 , and the lowest for cyan $\Delta E^{*}{ }_{50 \% \mathrm{C} \text { winter }}=3,81$.

The selection of colorants for ink jet application depends on the print performance requirements demanded by the specific use. Pigment-based inks have better stability than dye-based inks because of their crystalline structure.

Most of the cyan colorants used in ink jet printing with pigments are based on the copper phtalocyanine chromophore. This chromophore has good photo stability to most substrates. The most commonly used magenta pigments are dimethylquinacrid ones and have very high photo stability performance. Yellow pigments with high light fastness for ink jet applications are the monoazo acetoacetarylamides and isoindolines. Carbon black is used in pigment-based ink jet inks. This ink has high optical density and good prints stability. The mechanism of photo fading of colorants is oxidative fading in the presence of light, moisture and oxygen.

For UV curable inks, a polymerisation reaction leads to solidification of the ink and for this reason the absorption or diffusion is not important. Printer Roland UV LEC 300 uses ECO UV curable inks and pigments: Blue 15, Red C.B.I., Yellow 150, Carbon black and titanium dioxide.

In colour reproduction gamut gives an overview of overall scoop of colour information, including tone, saturation and lightness. By using the gamut volume light fastness of print can be traced to determine the fading rate and compare the light fastness of prints obtained from different printing techniques or different media.

In Figure 2 the 3D and 2D colour gamut with characteristic cross section (L50, L80) obtained with piezoelectric inkjet technology with pigment-based inks and $3 \mathrm{D}$ and 2D colour gamut for sections L20, L50 and 
L80 for piezoelectric inkjet technology with UV curable inks are presented.

On prints obtained on printer HP 9000s exposed to external conditions during the winter following the trend of seven-day dynamics of gamut volume decreases $\left(\Delta V_{\text {after }}\right.$

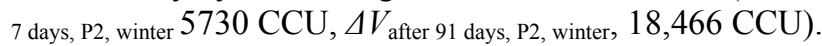
In these prints it is characteristic that in the top cut of gamut body (lighter tones) L20 gamut is not noticed. In the central section of gamut body L50 shows that the tones of magenta and cyan change the most. Winter exposing of prints will affect the change of tones which have a high chromatic value at $+b$ coordinate, or contain a higher percentage of yellow (section L80\%).
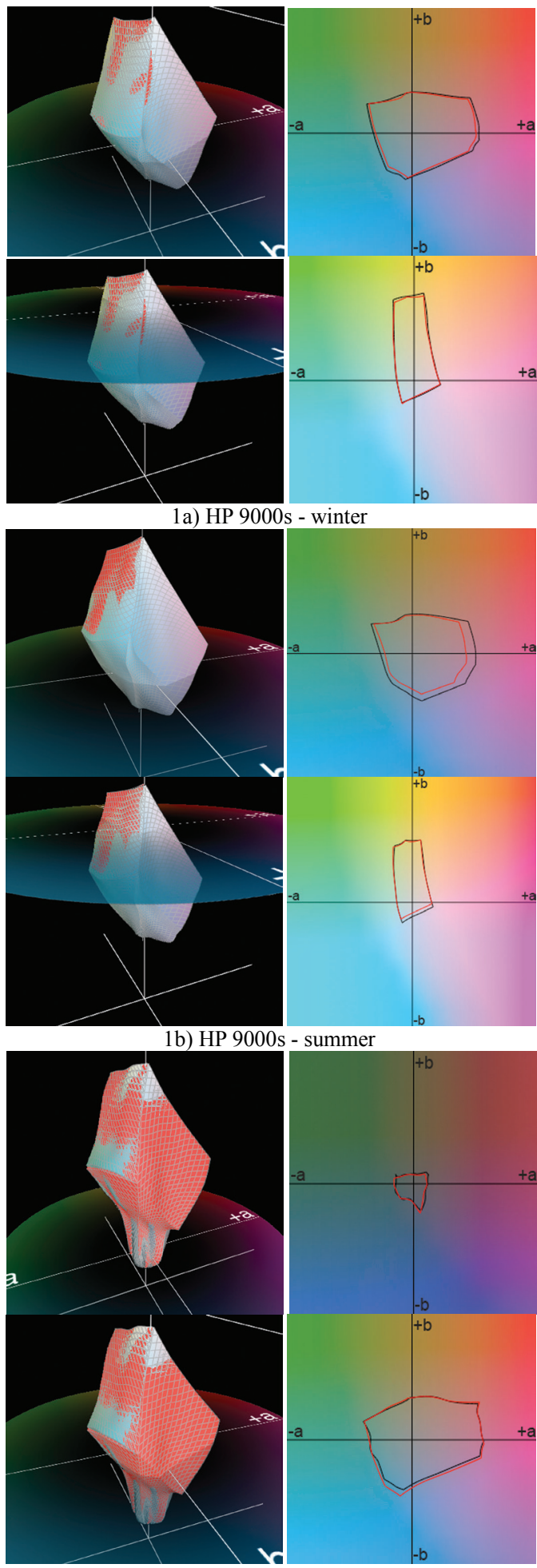

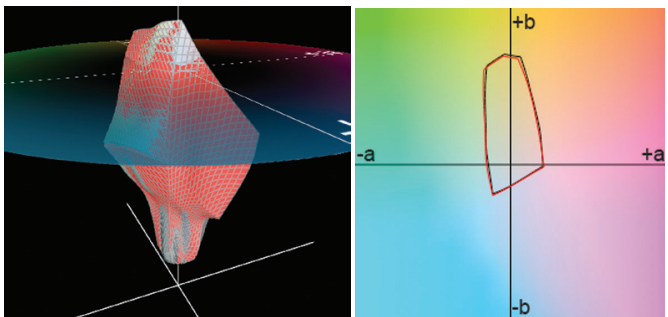

2a) Roland Versa LEC UV 300 - winter

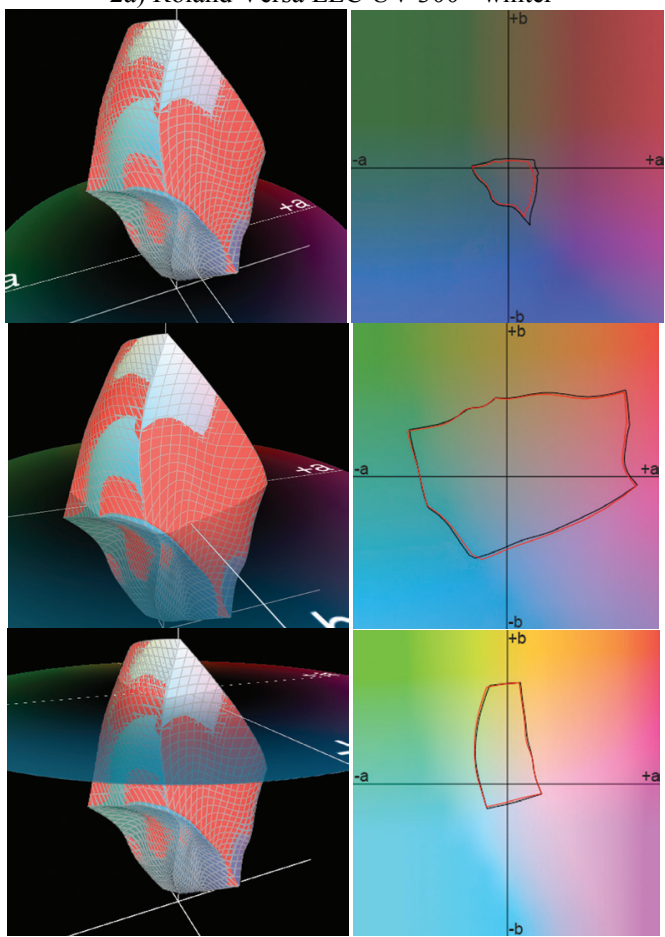

2b) Roland Versa LEC UV 300 - summer

Figure $23 \mathrm{D}$ and 2D colour gamut characteristic of the L50 and L80 for HP 9000s prints exposed during the winter and summer (1a and 1b) and 3D and 2D colour gamut for sections L20, L50 and L80 for Roland

Versa UV LEC 300 prints exposed in winter and summer ( $2 a$ and $2 b$ ).

By exposing the prints in the same time intervals in the summer, there is an even greater gamut reduction than exposing prints during winter $\left(\Delta V_{\text {after }} 7\right.$ days, $\mathrm{P} 2$, summer 6881

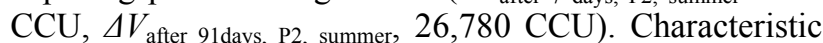
sections of gamut are similar to previously described, however, a greater intensity in changes occurs.

Observing gamut volumes of prints obtained with piezoelectric inkjet technology and UV curing inks exposed to outdoor conditions as described above determines the opposite values flow in relation to the prints with piezoelectric technology with pigment-based inks. In this case the gamut volume increases with time exposure $\left(\Delta \mathrm{V}_{\text {after }} 7\right.$ days, $\mathrm{P} 3$, winter $-12,861 \mathrm{CCU}, \Delta V_{\text {after }} 91$ days, P3, winter $-14,017 \mathrm{CCU})$. However, gamut volumes, within the observed time interval change less compared to the gamut volumes of another printer $\left(\Delta V_{7} / 91\right.$ days, $\mathrm{P} 2$, winter $12,736 \mathrm{CCU}, \Delta V_{7 / 91}$ days, $\mathrm{P} 3$, winter $\left.1,156 \mathrm{CCU}\right)$. With prints obtained with UV dyes all characteristic sections can be observed. In characteristic gamut sections of $\mathrm{L} 20$ and $\mathrm{L}$ 80 differences in the lines are almost negligible. In section L50 tones have something stronger $b$ chromatic coordinate value. On prints exposed outdoor in the summer an increase in gamut volume with an exposure time of up to 70 days occurs, after which the gamut volume decreases $\left(\Delta V_{\text {after7 days } \mathrm{P} 3 \text {, summer }}-14,406 \mathrm{CCU}\right.$, 
$\Delta V_{\text {after70 days } \mathrm{P} 3 \text {, summer }} 0,013 \mathrm{CCU}, \Delta V_{\text {after91 days } \mathrm{P} 3 \text {, summer }} 16,454$ CCU). In characteristic sections L20, L50 and L80 there are no significant changes.

Increasing gamut volume of the prints with UVcurable ink in terms of external exposure could be interpreted by the fact that unlike other types of inkjet colorants, UV curable inkjet inks because of faster drying can make the formation of larger amount without fluctuations in the thickness of the printed surface. Photoinitiators as colorant ingredients have a role of absorption of UV radiation. Due to the coat thickness it is possible that all molecules of photo-initiator do not absorb UV radiation in the process of print drying, but some react when prints are exposed to outdoor conditions. This way may lead to the above-described specified gamut volume increase by exposing prints.

Tab. 4 shows an increase of gamut $\Delta \mathrm{V}$ during the winter exposure in relation to real outdoor conditions: air temperature and relative humidity, the average of the daily global radiation and the average of daily diffuse radiation.

Table 4 Gamut $\Delta \mathrm{V}$ in function of real outdoor conditions: air temperature, relative air humidity, global and diffuse radiation

\begin{tabular}{|c|c|c|c|c|c|}
\hline Exposure days & Gamut $\Delta \mathrm{V} \mathrm{CCU}$ & Air temperature ${ }^{\circ} \mathrm{C}$ & $\begin{array}{c}\text { Relative air humidity } \\
\%\end{array}$ & $\begin{array}{l}\text { Mean daily diffuse } \\
\text { radiation } \mathrm{J} / \mathrm{cm}^{2}\end{array}$ & $\begin{array}{c}\text { Mean daily global } \\
\text { radiation } \mathrm{J} / \mathrm{cm}^{2}\end{array}$ \\
\hline 63 & 13,522 & 1,39 & 60,00 & 35 & 93 \\
\hline 70 & 15,567 & 11,48 & 54,17 & 40 & 97 \\
\hline 77 & 15,898 & 8,61 & 60,51 & 38 & 89 \\
\hline 84 & 18,898 & 12,57 & 58,17 & 37 & 108 \\
\hline 91 & 18,466 & 13,30 & 57,49 & 50 & 114 \\
\hline
\end{tabular}

The table shows the results of exposing of the HP 9000 s prints during winter outdoors. In this period there is an increase in gamut volume and $\Delta E^{*}$ for CMYK. There was a correlation between these values and the average of the daily global radiation, which is by $54,5 \%$ higher compared to the rest of the winter period of exposure, and diffusion by $43,3 \%$ higher. Global solar radiation is the total amount of solar energy falling on a horizontal surface. The values are usually the highest in the clear sun conditions during the summer and lowest during winter or very cloudy days. Global solar radiation on the described location in the summer increased by $52,3 \%$ while at the same time $\Delta \mathrm{V}$ increased by $43,4 \%$ compared to the winter.

By exposing Roland Versa LEC UV 300 prints in winter the average increase of $\Delta \mathrm{V}$ is $13,5728 \mathrm{CCU}$ in the average global radiation of $66,6 \mathrm{~J} / \mathrm{cm}^{2}$. During the summer period to 70 days exposure to the average increase of the gamut $7,8223 \mathrm{CCU}$ then reduce the gamut of an average of 14, the CCU 3423 and 91 days of exposure. In doing so, the global radiation increased by $52,3 \%$ as already mentioned above.

Diffuse solar radiation is the total amount of solar energy falling on a horizontal surface from all parts of the sky apart from the direct sun. The values are usually highest during the cloudy conditions and lowest during clear sky days. Through the winter period of exposing prints average daily diffuse radiation is $29,46 \mathrm{~J} / \mathrm{cm}^{2}$, while in the summer period it is slightly larger and amounts to $37,01 \mathrm{~J} / \mathrm{cm}^{2}$.

Geographic location and positioning of the print will have a great affect on the weathering resistance of a print. Diffuse solar radiation is the total amount of solar energy falling on a horizontal surface from all parts of the sky apart from the direct sun.

Sunlight has the greatest effect on outdoor prints and damage is caused by the UV component. The principal effect of sunlight exposure is fading of the prints due to the effect of UV radiation on the pigments. Some pigments do not fade but become darker. Printing substrates are affected by exposure to sunlight and especially paper as it becomes yellow as already determined.

Geographic location and positioning of the print have a great affect on the weathering resistance of a print. Print exposed in a sunny environment with high temperature fades faster than one in the moderate climate zone. The map of Europe is divided into three zones as is presented in Fig. 3.

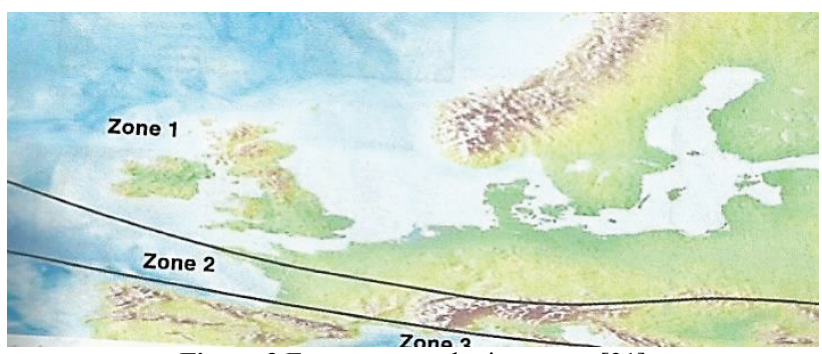

Figure 3 European weathering zones [31]

Prints from zones 2 and 3 have a shorter exposure life than the same prints in zone 1 [31]. Prints in zone 2 have an outdoor life about $60 \%$ than in zone 1 , and prints in zone 3 , about $50 \%$.

\section{Conclusions}

Based on the research results of the weather resistance of the Inkjet wide format prints obtained by piezoelectric technologies with pigment-based and UV curable inks and printing substrates which were exposed to the real conditions in intervals of 7 days throughout the whole winter and summer period and densely populated area of the city of Zagreb with heavy traffic, the following conclusions can be drawn.

The brightness of the printing substrate decreased and yellowness increased, due both to a yellowing of the paper and to the degradation of the optical brighteners as oxidative degradation of low molecular part of carbohydrates. The appearance is more noticeable in summer or when the paper is exposed to elevated temperature and humidity without radiation impact.

The value of $\Delta E$ may be defined as the difference between an exposed and unexposed print where the colour 
change due to weathering defines the amount of change of colour, but gives a lesser degree of change in one colour as compared to another. The highest colour difference was observed for black and magenta inks, depending on whether the print is exposed in winter or summer and whether the print is with full tone, or $50 \%$ raster. Volumes of colour gamut prints obtained with piezoelectric technology with pigment dyes with exposure to external conditions decrease with time. The average daily global radiation in summer is higher by $52 \%$ compared to winter, and $\Delta V$ gamut reduces by $43 \%$. Volume gamut with prints obtained with piezoelectric technology with UV dyes is increased by exposure to outdoor conditions in winter. Such change most likely occurs because of a delayed reaction of photo-initiators, which is allowed by thick layer of ink on the substrate. In the summer exposing of prints is after 70 days and in this case the gamut volume decreases with exposing.

Considering the results obtained in relation to the influence of meteorological factors on the stability of ink jet prints further research with longer duration (due to climate change), including new formulations of ink jet inks is justified.

\section{Reference}

[1] Lucas, J. Keep your true colors: Lightfastness and Weatherability testing. 2001. URL: http://www. inkware.com/html/vol.2_1.html (04.10.2014).

[2] Klemann, B. C. The development of Ink Jet media for outdoor applications. // Proceedings of the Conference on Recent Progress in Ink Jet Technologies / Springfield, 1999, pp. 356-359.

[3] Chapman, D. M.; Michos, D. Novel silica gels for glossy ink-receptive coatings. // Journal of Imaging Science and Technology. 44, 5(2000), pp. 418-422.

[4] Bondyopadhyay, S. Effect of paper properties on print quality of Ink Jet printers. // Proceedings of the NIP $17^{\text {th }}$ International Conference on Digital Printing Technologies / Fort Lauderdale, 2001, pp. 141-143.

[5] Chen T.; Burch T. High performance porous Ink Jet media derived from fumed silica. // Proceedings of $23^{\text {th }}$ International, pp. 110-113.

[6] Wu, Y. J.; Lovell, V.; Pokarovicova, A.; Fleming, P. D.; Joyce, M. Influence of coating pigment porosity on Ink Jet color and lightfastness performance. // International Circular of Graphic Education and Research. 5 (2013), pp. 6-17.

[7] DIN16525:1965-12 Testing of prints and inks for printing trade, resistance to various physical and chemical influences. Resistance to light.

[8] Chovancova-Lovell, V.; Fleming III P. D. Effect of optical Brightening agents and UV protective coating on print stability of fine art substrate for Ink Jet. // Proceedings of $22^{\text {th }}$ International Conference on Digital Printing Technologies / Denver, 2006, pp. 17-22.

[9] Vikman, K. Light fastness of Ink Jet prints on modified conventional coatings. // Nordic Pulp and Paper Research Journal. 19, 4(2004), pp. 481-488. DOI: 10.3183/NPPRJ2004-19-04-p481-488

[10] Halinova, B.; Jančovičeva, V.; Čeppan, M.; Hanus, J. Lightfastness of ink jet and laser prints. // Acta Chimica Slovaka. 1, 1(2008), pp. 95-111.

[11] Blaznik, B.; Mozina, K.; Bracko, S. Stability of ink-jet prints under influence of light. // Nordic Pulp and Paper Research Journal. 28, 1(2013), pp. 111-118. DOl: 10.3183/NPPRJ-2013-28-01-p111-118
[12] Chovancova, V.; Fleming, P. D.; Howell, P.; Rasmusson, A. Color and Lightfastness performance of different Epson ink sets. // Journal of Imaging Science and Technology. 49, 6(2005), pp. 652-659.

[13] Dobric E.; Bolanca Z.; Sindjic I. Gamut of Ink Jet prints in function of the environmental factors. // Scientific Book / Vienna, DAAAM International, 2009. pp.234-243

[14] Stepankova, E.; Dzik, P.; Vesely, M. Gamut volume as a tool for print lifetime estimation // Proceedings of the $5^{\text {th }}$ International Symposium GRID / Novi Sad, 2010, pp. 73-75.

[15] Bolanca Mirkovic, I.; Majnaric, I.; Sindjic, I.; Bolanca, Z. Colorimetric characteristic of Ink Jet prints in function of environmental parameter. // Proceedings of International Conference AIC / Zürich, 2011, pp. 280-283.

[16] Stepankova, E.; Dzik, P.; Fürst, T.; Vesely, M.; Smejkalova H. Print fading evolution using color gamut volume Change. // Book of Abstract of $1^{\text {st }}$ International Conference on Innovation in Art Research and Technology / Evora, 2013, pp. 84-84.

[17] Lajic, B.; Majnaric, I.; Bolanca, I. Accelerated and natural ageing of offset prints covered with different varnishes. // Nordic Pulp and Paper Research Journal. 28, 1(2013), pp. 101-111. DOI: 10.3183/NPPRJ-2013-28-01-p101-110

[18] Kačerova, S.; Vesely, M.; Dzik, P.; Štepankova, E. Chang gamut volume during long-term test. // Proceedings of XI Symposium on Graphic Art. / Pardubice, 2013, pp. 80-85.

[19] HP CB 271A BK Materials data safety sheet CB 272A $\mathrm{Cy}, \mathrm{CB} 273 \mathrm{~A} \mathrm{Mg}, \mathrm{CB} 274 \mathrm{~A}$ Ye, CB 275A light $\mathrm{Cy}, \mathrm{CB}$ 275A light Mg. http://www. hp com/us/(17.7 2014).

[20] Roland EUV, Cy, Mg, Ye, BK Wh, Material Safety Data Sheet. http://www.rolancare.com.an/support/ (17.7.2014)

[21] ISO 2470-1:2009, Paper, board and pulps Measurement of diffuse blue reflectance factor http://www.iso/ catalogue.det;/ISO $2470 /(18.7 .2014)$

[22] ISO 2471:2008 Paper and board-Determination of opacity, http://www.iso/catalogue.det;/ISO 2470 (19.7.2014)

[23] ISO 9416, Paper-Determination of light scattering and light absorption coefficient (using Kubelka-Munk theory). http://www.iso/catalogue.det;/ISO 2470 (19.7.2014)

[24] ISO 11475, Paper and board-Determination of CIE whiteness D65/10 degrees. http://www.iso/catalogue.det; ISO 2470iso/catalogue.det;/ISO 11475 / (21.7.2014)

[25] TAPPI T 524, Color of paper and paperboard. http://www.iso/catalogue.det/ISO 2470 ipstesting.com/ (25.7.2014)

[26] ASTM D 3424: Method 2, Outdoor weathering- Standard test methods for evaluating the relative lightfastness and weather-ability of printed matter

[27] DHMZ: Klimatoloski podaci http://www.klima.hr (30.7.2014)

[28] Luo, M. R.; Cui, G.; Rigg, The development of the CIE 2000 color difference formula: CIEDE 2000. // Colour Research Applied. 2, 5(2001), pp. 340-350. DOl: 10.1002/col.1049

[29] Johnson, T.; Green, P. The CIE 2000 colour difference formula and its performance with graphic data set. // Proceedings of IARIGAI $28^{\text {th }}$ Research Conference, Montreal, 2001

[30] Bolanca Mirkovic, I. Mechanism of deinking in function of paper ageing. Mg Thesis, University of Zagreb, Faculty of Graphic Arts, Zagreb, 2005

[31] Sericol Technical Services, Printers guide to weathering, http://www.secricol.co.uk (22.11.2014). 


\section{Authors' addresses}

Igor Sindjic, PhD student

University of Zagreb, Faculty of Graphic Arts

Getaldiceva 2, 10000 Zagreb, Croatia

E-mail: igor.sidjic@gmail.com

Ivana Bolanca Mirkovic, Assist. Profesor, PhD

Universiti of Zagreb, Faculty of Graphic Arts

Getaldiceva 2, 10000 Zagreb, Croatia

E-mail: ibolanca@grf.hr

Zdenka Bolanca, Profesor, PhD

Croatian Academy of Engineering

Kaciceva 48, 10000 Zagreb, Croatia

E-mail: zbolanca@hatz.hr 